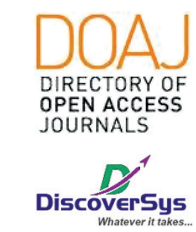

Published by DiscoverSys

\section{Karakteristik penderita suspect demam berdarah dengue berdasarkan penurunan trombosit di Instalasi Rawat Inap Puskesmas Tegalalang I tahun 2014-1015}

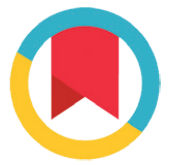

CrossMark

\author{
Pande Komang Gede Bayu Wikrama, ${ }^{1{ }^{*}}$ I Wayan Putu Sutirta Yasa ${ }^{2}$
}

\title{
ABSTRACT
}

Introduction: Dengue hemorrhagic fever are found in sub-tropic area and tropical. In the last 50 years, the incident has increased 30 times in the world. World Health Organitation with more than $70 \%$ of the population are at risk of dengue lives in Asia. In the year 2007 , Indonesia is a country of dengue hemorrhagic fever cases in Southeast Asia. Tegalalang is one of the district in Gianyar, which was having an increase in dengue hemorrhagic fever cases. This study aims to determine the characteristics of patients with suspected dengue fever based on a decrease in platelets in Inpatient Unit/ Installation of the Puskesmas (Public Health Centre) Tegalalang I in 2014-2015.

Methods: Study design using cross sectional model with secondary data from Puskesmas (Public Health Centre) Tegalalang I started in
January 2014 to June 2015. In the medical records of observable characteristics by sex, age, occupation, and decreased thrombocytes count began from the day third, fourth, and fifth of the fever.

Results: From 92 samples, $62 \%$ of men and $38 \%$ of women. The most samples between 15-24 years old and students are the most. Average thrombocytes on patients who began to be hospitalized on third day of the fever is $142.76 \times 10^{3} / \mathrm{ml}$. Average thrombocytes on patients who began to be hospitalized on four days of the fever is $123.22 \times 10^{3} / \mathrm{ml}$ and average thrombocytes on patients who began to be hospitalized on fifth day of the fever is $88.67 \times 10^{3} / \mathrm{ml}$.

Conclusion: It can be concluded that the number of thrombocytes decrease in patients with suspected dengue hemorrhagic fever can occurs on in the fever on day third, fourth and fifth.

Keywords: DHF, platelets, age, gender, occupation

Cite This Article: Wikrama, P.K.G.B., Yasa, I.W.P.S. 2019. Karakteristik penderita suspect demam berdarah dengue berdasarkan penurunan trombosit di Instalasi Rawat Inap Puskesmas Tegalalang I tahun 2014-1015. Intisari Sains Medis 10(2): 301-305. D0I: 10.15562/ism.v10i2.290

Latar Belakang:Demam berdarah dengue banyak ditemukan di daerah sub tropis dan tropis. Dalam 50 tahun terakhir, insiden telah meningkat 30 kali lipat di dunia. World Health Organitation mencatat lebih dari 70\% populasi beresiko dengue tinggal di Asia. Hingga tahun 2007, Indonesia merupakan negara tertinggi kasus DBD di Asia Tenggara. Tegalalang merupakan salah satu kecamatan di Kabupaten Gianyar yang mengalami peningkatan kasus DBD. Penelitian ini bertujuan untuk mengetahui karakteristik penderita suspect DBD berdasarkan penurunan trombosit di Instalasi Rawat Inap Puskesmas Tegalalang I tahun 2014-2015.

'Program Studi Pend idikan Dokter, FAkultas Kedokteran, Universitas Udayana

${ }^{2}$ Bagian Patologi Klinik, Fakultas Kedokteran Universitas UdayanaRSUP Sanglah Denpasar

${ }^{*}$ Correspondence to: Pande Komang Gede Bayu Wikrama, Program Studi Pend idikan Dokter, Fakultas Kedokteran, Universitas Udayana bayu.wikrama@gmail.com

Kata kunci : DBD, trombosit, usia, jenis kelamin, pekerjaan

\section{PENDAHULUAN}

Demam Berdarah Dengue (DBD) banyak ditemukan di daerah sub tropis dan tropis. Dalam 50 tahun terakhir, insiden telah meningkat $30 \mathrm{kali}$ jenis kelamin, usia, pekerjaan, dan penurunan jumlah trombosit mulai demam hari ketiga, keempat, dan kelima.

Hasil: Dari 92 sampel yang didapatkan 62\% laki-laki dan 38\% perempuan. Usia terbanyak sampel antara 15-24 tahun dan pekerjaan terbanyak sampel adalah pelajar. Rerata trombosit pada penderita yang mulai dirawat inap pada demam hari ketiga adalah 142,76x103/ml. Rerata trombosit pada penderita yang mulai dirawat inap pada demam hari keempat adalah $123,22 \times 10^{3} / \mathrm{ml}$ dan rerata trombosit pada penderita yang mulai dirawat inap pada demam hari kelima adalah 88,67x103/ml. Simpulan: Dapat disimpulkan bahwa penurunan jumlah trombosit pada penderita suspect demam berdarah dengue dapat terjadi pada demam hari ketiga, keempat, dan kelima. lipat di dunia. World Health Organitation (WHO) mencatat lebih dari 70\% populasi beresiko dengue tinggal di Asia. Hingga tahun 2007, Indonesia

Cite Pasal Ini: Wikrama, P.K.G.B., Yasa, I.W.P.S. 2019. Karakteristik penderita suspect demam berdarah dengue berdasarkan penurunan trombosit di Instalasi Rawat Inap Puskesmas Tegalalang I tahun 2014-1015. Intisari Sains Medis 10(2): 301-305. D0I: 10.15562/ism.v10i2.290 
merupakan negara tertinggi kasus DBD di Asia Tenggara. ${ }^{1}$

Penyakit DBD di Indonesia ditemukan pertama kali pada tahun 1968 dan sampai saat ini telah menyebar di 33 provinsi dan di 436 kabupaten/ kota dari 497 kabupaten/kota. ${ }^{2}$ Pada tahun 2014, sampai pertengahan bulan Desember tercatat penderita DBD di 34 provinsi di Indonesia sebanyak 71.668 orang, dan 641 meninggal dunia. Angka tersebut lebih rendah dibandingkan tahun 2013 dengan jumlah penderita sebanyak 112.511 orang dan jumlah kasus kematian 871 penderita. ${ }^{3}$ Angka kesakitan penyakit DBD dari tahun 1968 hingga saat ini cenderung terus meningkat yaitu 41,25 per 100.000 penduduk. Berdasarkan data Ditjen PP \& PL Kemenkes RI tahun 2013 tercatat Provinsi Bali memiliki angka kesakitan DBD tertinggi, yaitu 168,48 per 100.000 penduduk. $^{2}$

Kasus DBD di Bali setiap pada tahun 2011 terdapat 2.993 kasus dengan jumlah kematian 8 orang. Pada tahun 2012 terjadi penurunan kasus menjadi 2.649 kasus, 1.517 diantaranya berjenis kelamin laki-laki dan 1.132 berjenis kelamin perempuan. Gianyar adalah kabupaten urutan ketiga kasus DBD setelah Denpasar dan Badung pada tahun 2012 dengan 288 jumlah kasus. ${ }^{4}$ Pada tahun 2011 di Gianyar tercatat 208 kasus DBD dan terus meningkat setiap tahunnya. Berdasarkan data Dinas Kesehatan Kabupaten Gianyar, pada tahun 2013 terdapat 808 kasus DBD dan tahun 2014 meningkat dua kali lipat, yaitu 1783 kasus. ${ }^{5}$

Tegalalang merupakan salah satu kecamatan di Kabupaten Gianyar yang mengalami peningkatan kasus DBD. Angka insiden DBD tahun 2013 di wilayah Puskesmas Tegalalang I adalah 46 kasus per 100.000 penduduk dan meningkat 116 kasus per 100.000 penduduk pada tahun $2014 .^{5}$

Tabel 1 Karakteristik subjek penelitian

\begin{tabular}{llcc}
\hline Karakteristik Subjek Penelitian & Jumlah $(\mathbf{n}=\mathbf{9 2})$ & Persen $(\%)$ \\
\hline \multirow{2}{*}{ Jenis Kelamin } & Laki-laki & 57 & 62 \\
& Perempuan & 35 & 38 \\
\multirow{2}{*}{ Usia } & 5-14 tahun & 5 & 5,4 \\
& 15-24 tahun & 36 & 39,1 \\
& 25-44 tahun & 29 & 31,5 \\
& $>45$ tahun & 22 & 23,9 \\
& Buruh/ Tani & 8 & 8,7 \\
& PNS & 1 & 1,1 \\
& Pelajar & 30 & 32,6 \\
& Swasta & 29 & 31,5 \\
& Wiraswasta & 14 & 15,2 \\
& Ibu Rumah Tangga & 7 & 7,6 \\
& Tidak Bekerja & 3 & 3,3 \\
\hline
\end{tabular}

Puskesmas Tegalalang I berada di wilayah Kecamatan Tegalalang, Kabupaten Gianyar merupakan ujung tombak pelayanan kesehatan yang mempunyai tiga fungsi penting yaitu sebagai pusat pengembangan, pembinaan, dan pelaksanaan upaya kesehatan. Hal ini diperkuat karena Puskesmas Tegalalang I memiliki fasilitas rawat inap dan laboratorium. ${ }^{6}$

Melihat fenomena tingginya angka insiden DBD setiap tahunnya, peneliti disini tertarik untuk mendata karakteristik penderita suspect DBD dan menghitung rata-rata jumlah trombosit berdasarkan lamanya demam.

\section{METODE}

Penelitian ini merupakan penelitian cross sectional dengan pengambilan data sekunder dari Puskesmas Tegalalang I tahun 2014-2015. Penelitian cross sectional ini menggambarkan karakteristik penderita suspect demam berdarah dengue (DBD). Populasi dalam penelitian ini adalah semua penderita suspect demam berdarah dengue yang dirawat inap di Puskesmas Tegalalang I pada bulan Januari 2014 - Juni 2015. Jumlah sampel pada penelitian ini adalah semua suspect demam berdarah dengue yang dirawat inap di Puskesmas Tegalalang I pada bulan Januari 2014 - Juni 2015 berdasarkan data puskesmas. Pada penelitian ini, sampel ditentukan melalui metode non-probability sampling yaitu melalui metode konsekutif. Pada teknik penentuan sampel ini, setiap data dengan kriteria data lengkap sesuai kebutuhan penelitian dimasukan dalam analisis data. Variabel penelitian yang akan diidentifikasi adalah umur, jenis kelamin, pekerjaan, jumlah trombosit, dan lamanya demam. Instrumen dan bahan yang digunakan dalam penelitian ini adalah data sekunder yang berasal dari instalasi rawat inap Puskesmas Tegalalang I dan dari rekam medis. Data dikumpulkan, diolah, dan dianalisa secara deskriptif kemudian hasilnya disajikan dalam bentuk narasi, tabel, distribusi frekuensi, dan grafik.

\section{HASIL}

Data penelitian ini merupakan data sekunder dari hasil pengambilan data melalui catatan rekam medis pasien yang dilaksanakan pada bulan Januari 2014 sampai Juni 2015 di Instalasi Rawat Inap Puskesmas Tegalalang I. Penelitian ini bertujuan untuk mengetahui penurunan trombosit dan karakteristik penderita suspect demam berdarah dengue di Instalasi Rawat Inap Puskesmas Tegalalang I.

Subjek penelitian adalah penderita suspect demam berdarah dengue yang dalam periode waktu tersebut didapatkan 92 sampel dengan 
Tabel 2 Karakteristik subjek rawat inap mulai demam hari ketiga

\begin{tabular}{llcc}
\hline Karakteristik & & Jumlah (n=34) & Persen (\%) \\
\hline Jenis Kelamin & Laki-laki & 22 & 64,7 \\
\multirow{2}{*}{ Usia } & Perempuan & 12 & 35,3 \\
& 5-14 tahun & 2 & 5,9 \\
& 15-24 tahun & 14 & 41,2 \\
& 25-44 tahun & 9 & 26,5 \\
Pekerjaan & $>45$ tahun & 9 & 26,5 \\
& Buruh/ Tani & 5 & 14,7 \\
& Pelajar & 13 & 38,2 \\
& Swasta & 10 & 29,4 \\
& Wiraswasta & 4 & 11,8 \\
& Ibu Rumah Tangga & 1 & 2,9 \\
Nilai Trombosit & Tidak Bekerja & 1 & 2,9 \\
& $<140.000 / m l$ & 16 & 47 \\
& $<100.000 /$ ml & 1 & 2,9 \\
\hline
\end{tabular}

Tabel 3 Karakteristik Sampel Rawat Inap Mulai Demam Hari Keempat

\begin{tabular}{llcc}
\hline Karakteristik & & Jumlah $(\mathbf{n}=\mathbf{4 6})$ & Persen (\%) \\
\hline Jenis Kelamin & Laki-laki & 26 & 56,5 \\
\multirow{3}{*}{ Usia } & Perempuan & 20 & 43,5 \\
& 5-14 tahun & 3 & 6,5 \\
& 15-24 tahun & 17 & 37,0 \\
& 25-44 tahun & 15 & 32,6 \\
Pekerjaan & $>45$ tahun & 11 & 23,9 \\
& Buruh/ Tani & 3 & 6,5 \\
& PNS & 1 & 2,2 \\
& Pelajar & 15 & 32,6 \\
& Swasta & 15 & 32,6 \\
& Wiraswasta & 5 & 10,9 \\
& Ibu Rumah Tangga & 5 & 10,9 \\
& Tidak Bekerja & 2 & 4,3 \\
Nilai Trombosit & $<140.000 /$ ml & 38 & 82,6 \\
& $<100.000 /$ ml & 3 & $6,5 \%$ \\
\hline
\end{tabular}

distribusi sampel jenis kelamin laki-laki sebanyak 57 orang (62\%) dan jenis kelamin perempuan sebanyak 35 orang (38\%). Umur rata-rata sampel adalah 31 tahun 10 bulan dimana usia termuda dari sampel adalah berusia 12 tahun dan umur tertua berusia 80 tahun. Distribusi pekerjaan sampel paling sedikit adalah pegawai negeri sipil, paling banyak adalah pelajar. (Tabel 1)

Berdasarkan seluruh sampel pada penelitian ini, ada 34 orang yang mulai dirawat inap di Puskesmas Tegalalang I pada demam hari ketiga berdasarkan keluhan di catatan rekam medis. Rata-rata jumlah trombosit sampel saat mulai dirawat pada demam hari ketiga adalah $142,76 \times 10^{3} / \mathrm{ml}$ dengan nilai minimum $90 \times 10^{3} / \mathrm{ml}$ dan nilai maksimum $213 \times 10^{3} / \mathrm{ml}$. Jumlah trombosit sampel dibawah $140 \times 10^{3} / \mathrm{ml}$ sebesar $47 \%$ sampel, dimana $2,9 \%$ sampel jumlah trombositnya dibawah $100 \times 10^{3} / \mathrm{ml}$. (Tabel 2)

Sampel yang mulai dirawat inap pada demam hari ketiga terdiri dari 64,7\% laki-laki dan 35,3\% perempuan. Berdasarkan umur sampel yang paling banyak mulai dirawat inap sejak demam hari ketiga adalah umur 15-24 tahun $(41,2 \%)$ dan umur termuda berusia 12 tahun dan tertua berusia 78 tahun. Distribusi pekerjaan sampel yang dirawat inap sejak demam hari ketiga paling banyak adalah pelajar $38,2 \%$.

Pada penelitian ini ada 46 orang yang mulai dirawat inap di Puskesmas Tegalalang I pada demam hari keempat berdasarkan keluhan di catatan rekam medis. Rata-rata jumlah trombosit sampel saat mulai dirawat pada demam hari keempat adalah $123,22 \times 10^{3} / \mathrm{ml}$ dengan nilai minimum $84 \times 10^{3} / \mathrm{ml}$ dan nilai maksimum $164 \times 10^{3} / \mathrm{ml}$. Jumlah trombosit sampel dibawah $140 \times 10^{3} / \mathrm{ml}$ ada $82,6 \%$ sampel, dimana $6,5 \%$ sampel jumlah trombositnya dibawah $100 \times 10^{3} / \mathrm{ml}$. (Tabel 3)

Sampel yang mulai dirawat inap sejak demam hari keempat terdiri dari 56,5\% laki-laki dan 43,5\% perempuan. Berdasarkan umur sampel yang paling banyak mulai dirawat inap sejak demam hari keempat adalah umur 15-24 tahun dan umur termuda berusia 12 tahun dan tertua berusia 80 tahun. Distribusi pekerjaan sampel yang dirawat inap sejak demam hari keempat paling banyak adalah pelajar dan swasta. (Tabel 3)

Berdasarkan seluruh sampel pada penelitian ada 12 orang yang mulai dirawat inap di Puskesmas Tegalalang I pada demam hari kelima berdasarkan keluhan di catatan rekam medis. Rata-rata jumlah trombosit sampel saat mulai dirawat pada demam hari kelima adalah $88,67 \times 10^{3} / \mathrm{ml}$ dengan nilai minimum $60 \times 10^{3} / \mathrm{ml}$ dan nilai maksimum $127 \times 10^{3} / \mathrm{ml}$. (Tabel 4)

Sampel yang mulai dirawat inap pada demam hari kelima terdiri dari 75\% laki-laki dan 25\% perempuan. Umur sampel yang mulai dirawat inap sejak demam hari kelima termuda berusia 19 tahun dan tertua berusia 54 tahun. Distribusi pekerjaan sampel yang dirawat inap sejak demam hari kelima paling banyak adalah wiraswasta. (Tabel 4)

Berdasarkan rata-rata jumlah trombosit sampel yang dirawat inap di Puskesmas Tegalalang I mulai demam hari ketiga, keempat, dan kelima terjadi penurunan setiap harinya. Rerata trombosit pada penderita yang mulai dirawat inap pada demam hari ketiga adalah $142,76 \times 10^{3} / \mathrm{ml}$. Rerata trombosit pada penderita yang mulai dirawat inap pada demam hari keempat adalah $123,22 \times 10^{3} / \mathrm{ml}$ dan rerata trombosit pada penderita yang mulai dirawat 
Tabel 4 Karakteristik Sampel Rawat Inap Mulai Demam Hari Kelima

\begin{tabular}{llcc}
\hline Karakteristik & & Jumlah $(\mathbf{n}=\mathbf{1 2})$ & Persen (\%) \\
\hline Jenis Kelamin & Laki-laki & 9 & 75,0 \\
& Perempuan & 3 & 25,0 \\
Usia & 15-24 tahun & 5 & 41,7 \\
& 25-44 tahun & 5 & 41,7 \\
& $>45$ tahun & 2 & 16,7 \\
Pekerjaan & Pelajar & 2 & 16,7 \\
& Swasta & 4 & 33,3 \\
& Wiraswasta & 5 & 41,7 \\
& Ibu Rumah & 1 & 8,3 \\
& Tangga & & \\
Nilai Trombosit, rerata (min-max) & $\mu l$ & $88,670(60,000-127,000)$ \\
\hline
\end{tabular}

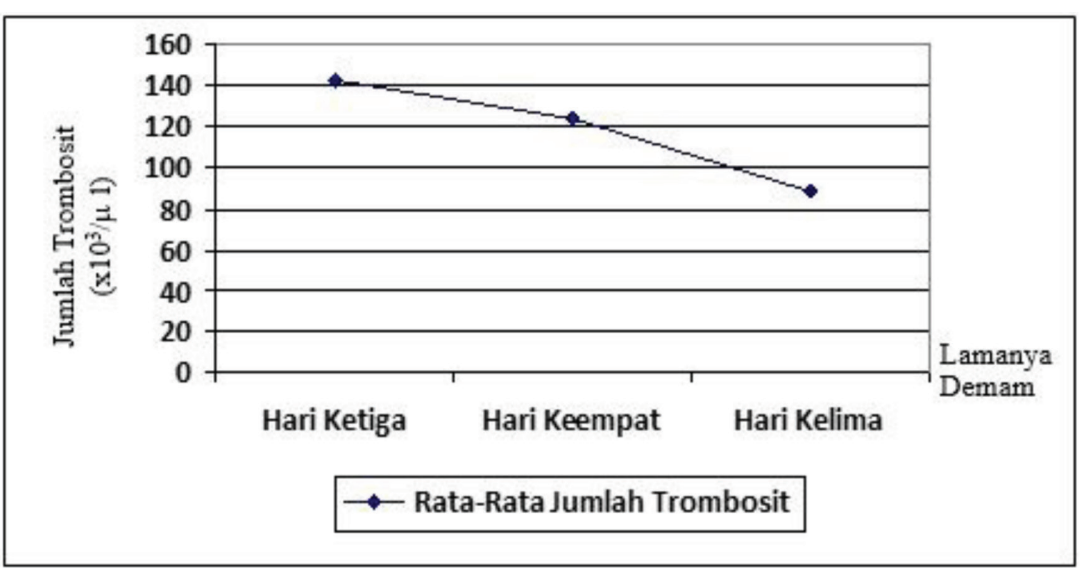

Gambar 1 Penurunan Rata-Rata Jumlah Trombosit Sampel

inap pada demam hari kelima adalah $88,67 \times 10^{3} / \mathrm{ml}$. (Gambar 1)

\section{PEMBAHASAN}

Demam Berdarah Dengue (DBD) dalam 50 tahun terakhir insidennya telah meningkat 30 kali lipat di dunia. World Health Organitation (WHO) mencatat lebih dari $70 \%$ populasi beresiko dengue tinggal di Asia. Hingga tahun 2007, Indonesia merupakan negara tertinggi kasus DBD di Asia Tenggara. ${ }^{1}$

Berdasarkan hasil yang diperoleh di Instalasi Rawat Inap Puskesmas Tegalalang I penderita yang dirawat inap dengan suspek DBD berjenis kelamin laki-laki sebanyak 57 orang (62\%) dan jenis kelamin perempuan sebanyak 35 orang (38\%). Persentase laki-laki yang dirawat inap mulai demam hari ketiga $(64,7 \%)$, keempat $(56,5 \%)$, dan kelima (75\%) juga lebih besar dibandingkan persentase perempuan. Hasil yang sama juga didapatkan pada penelitian berjudul Hubungan Antara Derajat Berat Infeksi Virus Dengue dan Kadar Natrium Serum dengan distribusi laki-laki 57\% dan perempuan 43\%. ${ }^{7}$ Pada Profil Kesehatan Provinsi Bali tahun 2012 juga menunjukan hasil penderita DBD yang berjenis kelamin laki-laki $57,3 \%$ dan perempuan $42,7 \%{ }^{4}$

Pada penelitian ini juga mendapatkan hasil umur terbanyak yang dirawat inap akibat DBD adalah usia 15-24 tahun sebesar 39,1\% dan diikuti usia 25-44 tahun sebesar $31,5 \%$. Hasil yang didapatkan pada penelitian berjudul Hubungan Antara Derajat Berat Infeksi Virus Dengue dan Kadar Natrium Serum, kelompok usia 21-30 tahun terbanyak yaitu 33,7\%. ${ }^{7}$ Dimana hasil yang berbeda didapatkan akibat perbedaan pengelompokan usia yang digunakan. Dilihat dari karakteristik pekerjaan pada penelitian ini didapatkan penderita DBD yang dirawat inap terbanyak adalah pelajar $(32,6 \%)$ diikuti swasta $(31,5 \%)$.

Pada penelitian ini juga menganalisa penurunan jumlah trombosit berdasarkan lamanya demam. Rerata trombosit pada penderita yang mulai dirawat inap pada demam hari ketiga adalah $142,76 \times 10^{3} / \mathrm{ml}$. Rerata trombosit pada penderita yang mulai dirawat inap pada demam hari keempat adalah $123,22 \times 10^{3} / \mathrm{ml}$ dan rerata trombosit pada penderita yang mulai dirawat inap pada demam hari kelima adalah $88,67 \times 10^{3} / \mathrm{ml}$. Bila mengacu pada pedoman WHO tentang DBD penegakan diagnosis salah satunya bila terjadi trombositopenia (jumlah trombosit $<100.000 / \mathrm{ml}$ ). ${ }^{1}$ Namun hasil penelitian menunjukan bahwa pada kasus dengue rerata jumlah trombosit di bawah 200 000/. $\mathrm{mm}^{3}$ ditemukan pada hari ke-3 panas dan di bawah $100000 / \mathrm{mm}^{3}$ di bawah hari ke- $4 .^{8}$

Hasil menunjukkan adanya kesesuaian antar hasil yang diperoleh dengan teori yang dikemukakan pada tinjauan pustaka dan penelitian sebelumnya bahwa hitung jumlah trombosit dapat digunakan sebagai alat bantu untuk diagnosis dengue karena menunjukkan sensitivitas yang tinggi mulai dari hari ke-4 demam sebesar $67.7 \%$, bahkan pada hari ke-5 sampai ke-7 menunjukkan angka 100\%. Spesifitas yang sangat tinggi pada penggunaan trombositopenia sebagai parameter disebabkan karena jarangnya penyakit infeksi yang disertai dengan penurunan hitung trombosit sampai di bawah 150.000/ml. Bahkan jika digunakan kriteria trombosit dibawah $100.000 / \mathrm{ml}$, spesifitas hampir mencapai $100 \%$ sejak hari pertama, namun mengurangi sensitivitas antara $10-20 \% .{ }^{9}$

Penelitian ini tidak terlepas dari berbagai kelemahan. Kelemahan ini disebabkan karena batasan yang dilakukan oleh peneliti dalam menentukan variable. Selain itu data yang digunakan pada penelitian ini merupakan data sekunder yang diambil dari rekam medis sehingga mengakibatkan adanya keterbatasan dalam pengolahan variabel perancu, serta terdapat faktor-faktor lain yang tidak diteliti yang mungkin akan mempengaruhi hasil penelitian. 


\section{DAFTAR PUSTAKA}

1. World Health Organization. Dengue Guidelines For Diagnosis, Treatment, Prevention and Control. Geneva: WHO. 2009.

2. Kementerian Kesehatan RI. Situasi Demam Berdarah Dengue di Indonesia. Jakarta: Pusat Data dan Informasi Kementerian Kesehatan RI. 2014.

3. Kementerian Kesehatan RI. Demam Berdarah Biasanya Mulai Meningkat di Januari. 2015

4. Dinas Kesehatan Provinsi Bali. Profil Kesehatan Provinsi Bali Tahun 2012. Denpasar: Dinas Kesehatan Provinsi Bali. 2013.

5. Dinas Kesehatan Kabupaten Gianyar. Data Laporan Kasus DBD di Kabupaten Gianyar tahun 2014. Gianyar: Dinas Kesehatan Kabupaten Gianyar. 2015.

6. UPT Kesmas Tegalalang I. Profil UPT Kesmas Tegalalang I Tahun 2013. Gianyar: UPT Kesmas Tegalalang I. 2013.
7. Budiyasa D, Merati K. Hubungan Antara Derajat Berat Infeksi Virus Dengue dan Kadar Natrium Serum. J Peny Dalam. 2011;12(1):21-32.

8. Rena NM. Kelainan Hematologi Pada Demam Berdarah Dengue. Jurnal Penyakit Dalam. 2009;10(3):222-223.

9. Suwandono A, Nurhayati, Parwati I. Perbandingan nilai diagnostic trombosit, leukosit, antigen NS1, dan antibodi IgM antidengue. Jurnal Indonesian Medical Association. $2011 ; 61(2): 8-12$.

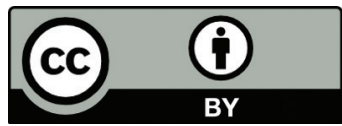

This work is licensed under a Creative Commons Attribution 